\section{Shortcomings halt study of Swiss cancer vaccine}

Quirin Schiermeier, Munich

A Swiss clinical trial of a vaccine against skin cancer has been scrapped after a government-backed investigation found "serious shortcomings" in its conduct.

The inquiry, which released its results on 28 November, says that the study's methods and medical examinations were insufficiently documented, its protocols inadequate, and that several patients were treated without prior written consent.

But Frank Nestle, the dermatologist at the University of Zurich who led the study, will not face sanctions because the Swiss federal health office's inquiry found that no scientific data had been manipulated and that patients had not been put at risk.

In 1998, Nestle reported tumour regressions in 5 out of 16 melanoma patients vaccinated with a fusion of dendritic cells from the immune system and tumour cells (F. O. Nestle et al. Nature Med. 4, 328-332; 1998). This success rate dropped substantially after more patients were included in the study.

But, according to the inquiry, only the earlier, more promising results were displayed on the clinic's website. This was the case until February, when the University of Zurich responded to complaints and set up an internal investigation of the study. The clinical trial was suspended on 17 April, and the Swiss federal health office commissioned its inquiry.

The Internet material was meant primarily for physicians, Nestle says. But he admits that he cannot exclude the possibility that new patients - including some non-Swiss nationals who were charged an average of SFr 9,000 (US\$7,000) to take part in the study could have been persuaded to participate because of the information on display.

Nestle says that he did not intend the website to be an advert for the study. "As an important cancer centre, we were allocated more than enough patients," he says. In addition, he notes that treatment costs were administered by the university's hospital management, which did not break existing guidelines. "There was, of course, no personal gain," he adds.

The initial Zurich work led to a larger, multicentre study of dendritic cells as a treatment for skin cancer, coordinated by the German Cancer Research Center in Heidelberg. Despite doubts about cancer vaccines now raised by the Zurich study, trials in Germany and Switzerland on more than 100 patients will continue.

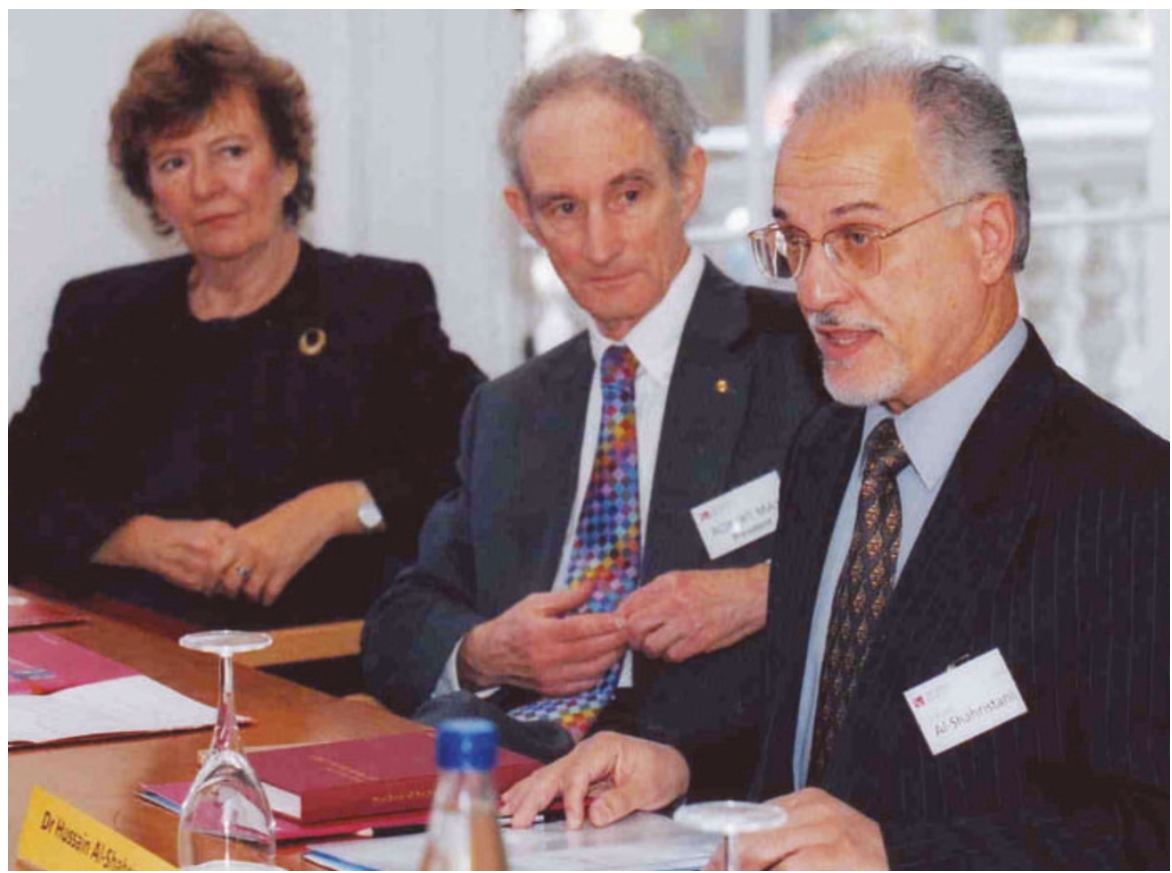

Royal Society officials meet with Hussain Al-Shahristani (right) to discuss next steps for Iraqi science.

\title{
Iraqis draw up blueprint for revitalized science academy
}

Jim Giles, London

A dozen Iraqi scientists and engineers met with officials of the Royal Society in London last week and agreed to set up an Iraqi academy of sciences. They said that the academy would help to develop a research strategy for the country.

Although most of the Iraqi participants work in Iraq, the meeting was held in London for security reasons, organizers said. Hussain Al-Shahristani, an exiled chemical engineer who initiated the meeting, says that the organization will be open to established scientists and engineers, and will be independent of the government. He is hoping to attract "a few hundred thousand pounds" from Western sources to set up the body, whose first full meeting is planned for next November in Baghdad.

A former senior adviser to the Iraqi Atomic Energy Commission, Al-Shahristani says that he was imprisoned and tortured during Saddam Hussein's regime for refusing to work on an atomic-weapons programme. He escaped from Iraq in 1991, when Baghdad was bombed during the first Gulf War, and is currently a visiting professor at the University of Surrey, UK.

Al-Shahristani suggests that establishing environmental studies of biological, chemical and radiological pollution should be a priority for the academy. In particular, he would like to find out whether the pollution, some of which was caused by weapons-testing programmes, is linked to an increase in cancer rates that has been reported in the country.

Other exiled participants said that they were unsure if they would ever return to Iraq. Farhan Bakir, former personal physician to Saddam Hussein, left in 1981 after being forced into early retirement. Bakir says that he feared for his safety.

"People were being killed and arrested," he recalls. "I was insecure, but so was everyone in Iraq." Bakir, currently at the Western University of Health Sciences in Pomona, California, says that he would like to go back, but will wait until things are more settled. "I'm over 70," he jokes. "I'll take an advisory position at this age."

The Iraqi Academy of Sciences that operated under Saddam had few international contacts, and has now ceased to function. Critics say that it was directly controlled by officials close to Saddam. Huda Salih Mahdi Ammash, an Iraqi microbiologist who was reportedly a senior figure in the country's biological-weapons programme and is now in US custody, ran the academy from the mid-1990s.

But nuclear, chemical and biological weapons pose a dilemma for the new academy. Scientists at the London meeting said that those involved in developing weapons of mass destruction would not be allowed to join. But Al-Shahristani acknowledges that some scientists had little choice about the area they worked in. "People know who was forced into weapons work," he says. "We'll look at it on a case-by-case basis." 